総 說

\title{
學振における電刷子研究の業績
}

前學振 117 委員會委員長 宗 宮 知 行

\section{(Research Works on Carbon Brushes in Japan Society for the \\ Promotion of Research)}

Tomoyuki Somiya

前號まで

(1) 緒言 (2) 菜績の全貌 (3) 炭素刷子の物理 的特性並飞测定法 a. 比重 b. 彈性係數 c. 摩擦 係數 d. 衝擊耐力 e. H.D.R. 特性 f. 整流圾驗 g. 固有抵抗, 硬度及び抵抗力 h. 物理的諸性質の 测定值 i. 摩擦係數の均一性 (4) 滕止並に替動 接觸に閣する研筧 a. 電子备折による黑鉛縻擦面 の研究 b. 銅整流子面の構造及び性質

\section{（c）接觸電壓降下}

一般に別子の接觸電壓降下々電氣機械の電壓並 そ電流の大小に對して適當を刷子を撰摿するに虽

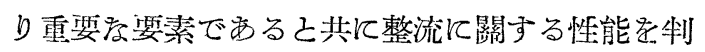
斷する標準とされて居た。然しながらその後研究 の結果今日では刷子の合理的を低々摩擦係數, 適 嫦な雒性係數及び整流子面上飞良好をる皮膜学常

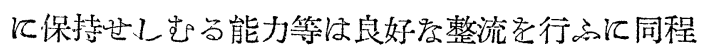
度に重要を因子である事が明にされた。

接觸電壓降下は揸動面狀態の變化により非常に變 化するるので定量的にも定性的にも不明の點老數 多く残して屈る。

接儥電壓降下影響を持つるのの一つとして整 流子面上の皮膜基舉げる事が出來る.この表面皮 膜は運轉狀況及び大氣の狀態で非常に變化し，又 この皮膜中に存在する亞陖化銅の薄層及びそれに 附着する黑鉛微結旨並飞表面の吸着水, 油類等は 整流特性，接觸電壓降下に大るる影響を與へる。

この皮膜は或る場合には電解作用によつて，或 る場合に刷子の研磨作用によつて時に刻飞變化 して居る己考へてよい，敌に刷子及び整流于の表 面を擴大して描けば第 34 圖の如き斷面に類似し て居るのであらう。
硫化物或注油の皮膜の存在は過剩の接觸電壓を 來えし，大氣中の鹽素の存在は皮膜に惡影響を與 へ電壓降下客含動作特性を著しく害する。

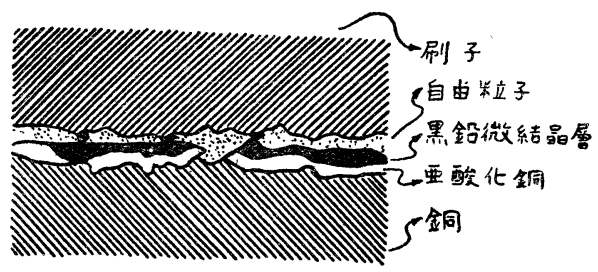

Fig. 34

その他整流子表面溫度, 刷子振㗢等も大んに影 響する. 電氣的方面では整流起電力, 短絡線輪中 の誘起起電力により刷子下各部分の流通電流が變 りその爲に電壓降下方變化する事も明である。從 來按觸電壓降下测定法として，ピグラ゙ールと刷子 の觸れてわる整流子上の點との間の電壓を數箇所 测定して刷子電壓帅線を得て居るが，ての静的特 性は不充分であつて，動的刷子電厴啲線が必姴で ある事が强調された、とれ㓌極線オシログラフ を使用する事によつて賽驗出來るので西つて目下 各方面で研觉中でする。刷子壓力几關しては吉田 喜久次委員の經驗によ礼哭鉛化程度の進えだ刷 子では $200 \mathrm{gr} / \mathrm{cm}^{2}$ 前後を探る己良好な整流子面 獎態を得る. Hellumund によ冯刷子面下の火 花は接觸電壓降下が滑嘢環を肺ひた場合大體 3.2 V 以上にをつを㭙起り易い事を述へて居る. 故に 刷子により短絡せられそ電機の線輸內の電壓を適 當に制御するには略 $1 \mathrm{~V}$ 前後の刷子電壓降下が望 ましん.

䅛動接觸抵抗の特徴の一つ壮抵抗が電流の變化 に件つて大きく變化する事で西る。刷子が良好を る接觸抵抗、換言すれば適嫦劣る接觸電壓降下を 
有する場合には，已に刷子の下に在当整流子片か ら今将に接觸に移らんとする整流子への急激を電 流の轉移を抑入，又将に刷子亡の接觸学離れ九之 する整流子片の電流を製限して火花の發生を防ぐ で密らう．接觸抵抗が刷子の極性によつて相當異 る點等に閣しても研究すべき開題が残されて居

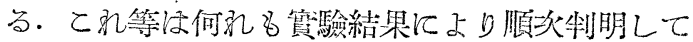

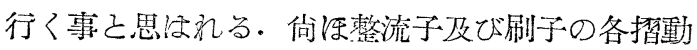

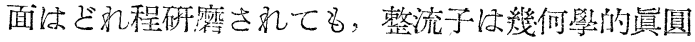

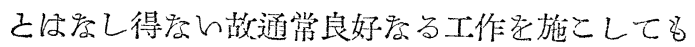
運轉狀態では $0.02 \mathrm{~mm}$ 程度の偏心は觉る名の之

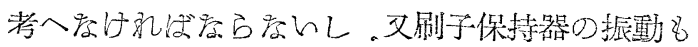

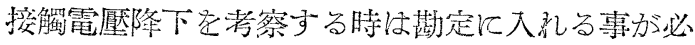
要で尚ら。.

\section{(d) 火花量の測定}

電流火花の事に關しては (f) 整流試驗の項に於 んて少し述べを・本委員會に於んては，發生しを

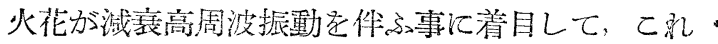
它檢波增輻して火花强弱定表現する方法が提出さ

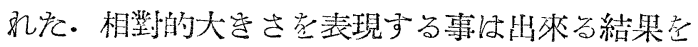

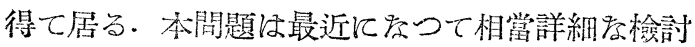
が行は色々孝方法分提案されて居方名 “炭素” の研究報告にのせる事にして省略する。

\section{（e）熱起電力, 熱傳導度}

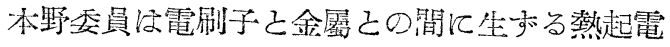
力に關し研究されを・筀素瓦斯中で銀この間に起 こる熱起電力は電氣黑鉛刷子では黑鉛化の進んだ もの程大體に於いて起電力が大ですり，大きいも

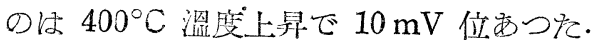

天然黑鉛刷子では熱起電力が少く各種刷子で大體 同一値を示した・その數值は溫度上昇 $400^{\circ} \mathrm{C} て ゙$ 大體, $0.3 \mathrm{mV}$. ナショナ几製 TA 系屬する刷子 の熱起電力腈線を 1例己して第 35 圖に搨げる.

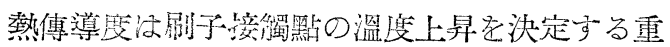

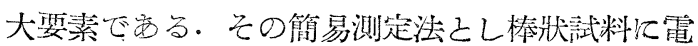
流它通じての溫度上显から次式により求的られを

$$
\frac{V^{2}}{8, k \rho}=T m-\frac{T_{1}+T_{2}}{2}
$$

$\rho$ は固份抵抗， $k$ は熱傳導率， $V$ は溫度 $T_{1}$ 己 溫度 $T_{2}$ 默筑電壓， $T m$ は試料中央の溫度

NCCSA 系で (0.26-0.22), NCCTA 系 $(0.28$ $-0.22)$, OS6 は 0.79 で测定値中の最大值を示 し、C-4 が 0.08 で最小檤, NCC-258 は 0.63

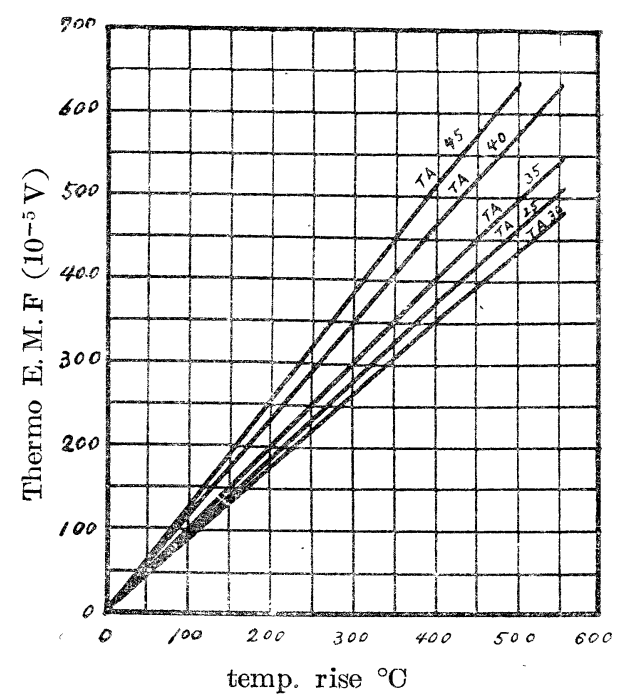

Fig. 35

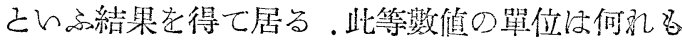
Watt $/{ }^{\circ} \mathrm{C}, \mathrm{cm}$ である。

\section{(f) 最高接触電壓}

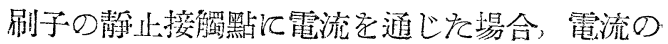

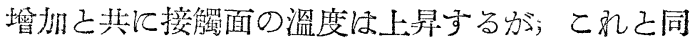
時に接觸抵抗は減して溫度は降下せんるする。上 界效果亡降下效果分汗衡すると或る一定溫度に存 るわけである。この溫度は材料特有のものであ る. 接觸點の溫度上昇之㑕觸點閒の電位差 $V$ との 間に注，次の距係分西る。

$$
\Theta=\frac{V^{2}}{8 k \rho}
$$

$k$ 以熱傳導度, $\rho$ は固有抵抗心何孔も溫度に無 關係とした、溫度が一定である叭ら掌然電位差 $V$

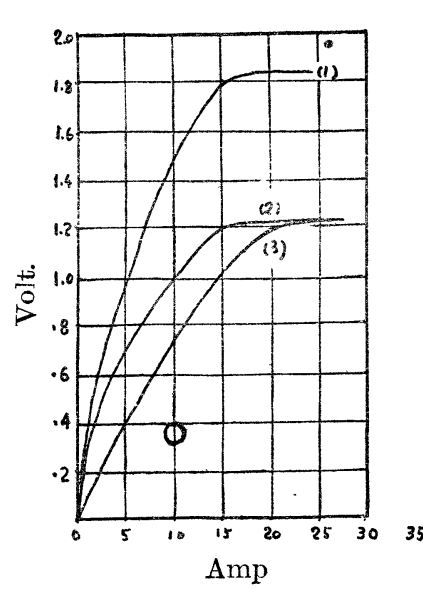

Fig 36 は一定で放りとの電 壓は金屬接觸をして 居る際の最高電壓で 西る。細心质注意の 下に行つ崖测定例定 第 36 圖飞示す. 横 軸は、妾點通過電流で 縱抽梳接觸電壓を示 与. 第36圖の (2) 己 (3) 曲線は同一筫の ものであり最初の脺 觸狀況で溫度上昇の 樣子は異るが最高接 
觸溫度蛙同一である。手阡に在つた刷子につんて の测定結果によればとの電厴住 $2.31 \mathrm{~V}$ から 1.11 Vの範園內に出つそ. 電厴の咅刷子は電流密度

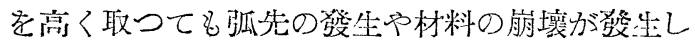
難的工想像出來子。若し, 熱傳導度 $k$, 固倠抵 抗 $\rho$ ガ既知であればての最高接觸電壓を测定する

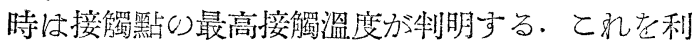
用しーC测定しを結果は接觸點の溫度は大體 $400^{\circ} \mathrm{C}$ 一 $500^{\circ} \mathrm{C}$ で㐫り，て礼は丁度炭素の酒化開咍の溫 度に略々等しん。 今最高溫蓝の平均值 $450^{\circ} \mathrm{C}$ と

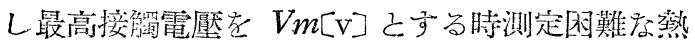

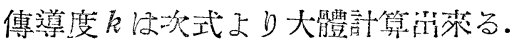

$$
k=\frac{V^{2}}{36000^{\circ}}
$$

但し $\rho$ 纺オームで表はされて居る。

\section{(5) NCC 社 SA 系刷子の性能}

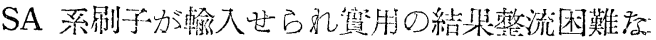

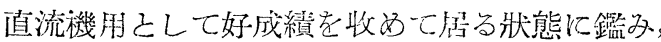
それらの特性を調查し一優唀國﨎品商出の一助を らしむ心゙く本委員會は，SA 系 5 種资入手し各委 員の手許で各程の試䌞調查を行ゔ。. その結果を ことに綜合したわけで方名各测定者によつて教

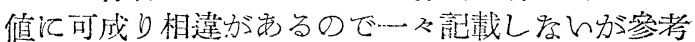
までに各委員の测定值它平均して一覧すると次の 遖りである。

\begin{tabular}{|c|c|c|c|c|c|}
\hline \multirow{2}{*}{ 項 } & \multicolumn{2}{|c|}{ 試 } & \multicolumn{3}{|c|}{ 料 } \\
\hline & SA 25 & $\mathrm{SA} 30$ & SA 35 & SA 40 & $\mathrm{SA} 45$ \\
\hline 固有抵抗 $\mathrm{ohm} \mathrm{cm}$ & 0.0051 & 0.0055 & 0.0060 & 0.0062 & 0.0070 \\
\hline 比重 & 1.63 & 1.58 & 1.55 & 1.54 & 1.50 \\
\hline 重 & 1. 993 & 1. 973 & 1.979 & 1.989 & 1. 988 \\
\hline 孔 率 \% & 17.2 & 19.84 & 21.2 & 21.1 & 23.7 \\
\hline 吸水 量 $\left(\mathrm{gr} / \mathrm{cm}^{2}\right)$ & 0.15 & 0.17 & 0.17 & 0.19 & 0.19 \\
\hline 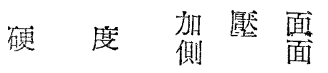 & $\begin{array}{l}55 \\
51\end{array}$ & $\begin{array}{l}48 \\
43\end{array}$ & $\begin{array}{l}47 \\
42\end{array}$ & $\begin{array}{l}44 \\
40\end{array}$ & $\begin{array}{l}39 \\
38\end{array}$ \\
\hline 擊 値 $(\mathrm{kg} / \mathrm{cm})$ & 0.702 & 0.663 & 0.555 & 0.703 & 0.677 \\
\hline 性 率 $\left(\mathrm{k} . / \mathrm{cm}^{2}\right)$ & 873 & 686 & 628 & $\tilde{6} 45$ & 467 \\
\hline 抵 抗 力 $\left(\mathrm{kg} / \mathrm{cm}^{2}\right)$ & 358 & 191 & 152 & 131 & 104 \\
\hline 抗 嫄 力 $\left(\mathrm{kg} / \mathrm{cm}^{2}\right)$ & 780 & 446 & 392 & 360 & 266 \\
\hline 抗 張 力 $\left(\mathrm{kg} / \mathrm{cm}^{2}\right)$ & 51 & 35 & 34 & 27 & 21 \\
\hline 分 \% & 0.11 & 0.08 & 0.08 & 008 & 0.09 \\
\hline 熹热膨 脹 係 數 $\left(10^{-6}\right)$ & 4. 8 & 4.9 & 4. 2 & 4. 2 & 3.9 \\
\hline 熹 傳 薄度 $\mathrm{W} / \mathrm{cm} /{ }^{\circ} \mathrm{C}$ & 0.032 & 0.027 & 0.046 & 0.032 & 0.026 \\
\hline 攀 擦 係 & 0.23 & 0.25 & 0.23 & 0.25 & 0.25 \\
\hline
\end{tabular}

整流試薟の結果注大體 SA 25 から SA45 の順に 整流性能々良好で的る。衙䛨試驗器にるる缺損試 驗は，衙撃耐力は（Hrs）で示した時 SA 25一 85, SA 30-70, SA 35-55, SA 40-15, SA 4515. スパークによ方渻耗試驗として直徑 7.4 麊,
長さ 13 籷の供試刷于と金屬淁觸子との間に 100 V. 1.5A の電流により1分閒37回の開関を行は

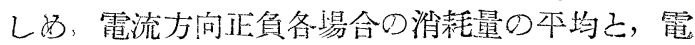
流の方向にをる渻耗量の制合を研究した。

\begin{tabular}{|c|c|c|c|c|c|}
\hline 項 & $\mathrm{SA} 25$ & S A 30 & S A35 & $\mathrm{S} \mathrm{A} 40$ & $\mathrm{SA} 45$ \\
\hline 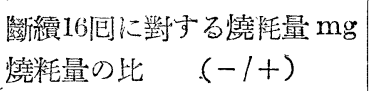 & $\begin{array}{r}103 \\
4.00\end{array}$ & $\begin{array}{r}128 \\
2.85\end{array}$ & $\begin{array}{r}150 \\
2.35\end{array}$ & $\begin{array}{l}156 \\
1.75\end{array}$ & $\begin{array}{r}193 \\
1.30\end{array}$ \\
\hline
\end{tabular}

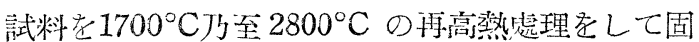
有抵抗を测定した結果その變化の割合が梪的て小 であつた。酸化溫度は SA $25-626^{\circ} \mathrm{C}$ SA 30 $590^{\circ} \mathrm{C}$ SA $35-622^{\circ} \mathrm{C}$ SA $40-640^{\circ} \mathrm{C}$ SA $45-$ $706^{\circ} \mathrm{C}$ 乙の测定結果名報告されて居る.

\section{（6）國産黑鉛化刷子の成績}

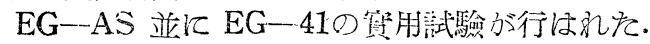
是等の刷子は，日本學術振興命第18小委員會第 1 分科會江於ける電機朋别于の其礎的研究並に同特 别委員會の指導により日本カーボン株式會社に於
て製作せられたものである。電解工瑒, 電鐵等に 劫ける使用狀態とその成績が詳細飞研究調㭗せら れたので哥つて，其當時に於いては外國製品に比 して遜色のない絬果跑て居る。然し最近の電氣

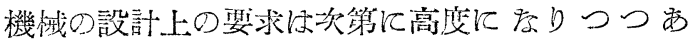
り，從つて益及品質の向上が刹望さるる現狀他 る。其當時尾河珷雄委員怕各種刷子の整流試驗を 行ひ束海電極製 OS 602 落速電機化裝着した所 SA 45 と匹敵した成縝を得を己報告して居る。 